\title{
Effect of elevated accumulation of iron in ferritin on the antioxidants content in soybean sprouts
}

\author{
Magdalena Zielińska-Dawidziak • Aleksander Siger
}

Received: 25 February 2011/Revised: 16 February 2012/ Accepted: 28 February 2012/Published online: 25 March 2012

(C) The Author(s) 2012. This article is published with open access at Springerlink.com

\begin{abstract}
Cultivation of soybean sprouts in abiotic stress conditions, resulted from the presence of 5-25 $\mathrm{mM} \mathrm{FeSO}_{4}$ in the culture media, causes a strong overexpression of ferritin. Accumulation of ferritin iron in sprouted seeds germinated in the $20 \mathrm{mM}$ solution of $\mathrm{FeSO}_{4}$ was 67 times higher than in sprouts germinated in distilled water. The cultivation conditions also influence on another antioxidant contentmainly $\beta$-carotene content, which increased 28 times (in sprouts cultured in $10 \mathrm{mM} \mathrm{FeSO}_{4}$ solution) in comparison to the content in dry seeds. Obtained in stress conditions sprouted seeds contain less tocochromanoles than raw seeds. However, their total tocochromanol content was higher than in sprouted seeds cultured in distilled water in every examined concentration of $\mathrm{Fe}^{2+}$. A total antioxidant activity is increased only during culturing in $0-10 \mathrm{mM}$ media, and it is positively correlated to the total phenolic compounds content $(r=0.8498)$. We concluded that germination in high abiotic stress also causes the increase in different antioxidants content, not only in ferritin, which is directly involved in the process of iron detoxification.
\end{abstract}

Keywords Biofortification - Soybean sprouts - Ferritin . Tocopherols · Tocotrienols $\cdot$ Phenolic compounds

\section{Introduction}

Maintaining body iron homeostasis is essential for the proper functioning of human body. Lack of iron leads to anemia, and

M. Zielińska-Dawidziak ( $₫) \cdot$ A. Siger

Department of Biochemistry and Food Analysis,

Poznan University of Life Sciences, Mazowiecka 48,

60-623 Poznan, Poland

e-mail: mzd@up.poznan.pl an excess to serious disorders resulting from primary (hemochromatosis), and secondary iron accumulation in the body (thalassemia, anemia of chronic disease, chronic viral hepatitis, alcoholic cirrhosis) [1-4]. Anemia is a common problem throughout the world and iron deficiency is the most prevalent nutritional deficiency in the world. It affects mainly the poorest segment of the population, particularly where malnutrition is predominant and the population is exposed to a high risk of water-related infection. According to World Health Organization (WHO), about 2 billion people suffer from anemia. The problem is particularly evident in developing countries where $90 \%$ of people live with iron deficiency anemia [5]. Iron deficiency anemia is defined as the one that occurs when iron loss (often from intestinal bleeding or menses) occurs, and/or the dietary intake or absorption of iron is insufficient. In the second case, even if the supply of the microelement in the diet is quite high, the problem is often related to its bioavailability. In nonvegetarian diet, only 10-15\% of supplied iron is absorbed in the entherocytes of the duodenum. In the diet based on vegetables, the bioavailability is much lower [6]. The absorption of iron is strictly regulated, controlled, and enhanced in the time of increased demand for this microelement [7]. Therefore, the simplest method of preventing the development of anemia is iron supplementation. The supplementation may take various forms and is associated with various technical problems, such as proper selection of matrix, the balancing of inhibitors and enhancers, supplement stability, acceptability, costs and benefits of its intake $[8,9]$. Therefore, an effective way to introduce a population level of iron in the food chain is still desired. The new, good source of iron should both limit its losses from food and increase its assimilation by the human body.

One of the directions indicated by the WHO for the prevention of anemia is the fortification of food in a readily 
absorbable form of iron [10]. Biofortification of edible parts of plants is postulated as the one of the alternative methods for the introduction of micronutrients (including iron) to the food chain [11]. Plants are an essential component of the food chain. The appropriate plants growth and thus the processes of synthesis of organic compounds are determined by the absorption of minerals from the soil. Due to the potential toxicity of many minerals present in soil, plants tightly regulate the processes of their imbibition and storage. Due to the adverse effects of both deficiency and excess of iron in the cell, the absorption of these ions involves various transporters and storage options [12]. Iron is stored in vacuoles, apoplasmic space, and first of all in plastids, as ferritin [13]. Ferritin is sphericeral protein cage around nanomineral of hydrated ferric oxide. The protein is able to accumulate up to 4,500 iron atoms in the apoferritin shell [14]. High accumulation of phytoferritin is observed especially in iron-rich organs (such as legume seeds) and synergistic bacteroids of leguminous root nodules [15].

Germination of soybean changes a level of almost all constituents present in raw seeds. As a result of proteolysis, the content of proteins decreases and simultaneously the content of amino acids and non-protein nitrogen increases $[16,17]$. The lipids content is progressively lowered during germination [17]. Despite the fact that high activity of amylases is observed, an increase in starch content is noted [18]. Dietary fiber is reduced [19], but changes in mineral content depends on germination conditions [17]. The level of most vitamins is also increased [20]. Furthermore, sprouting decreases the content of antinutrients such as trypsin inhibitors, phytic acid, and galactosides [21, 22].

However, there is little data about the impact of biofortification during germination in abiotic stress conditions such important compounds as natural antioxidants. The aim of the experiment is to examine whether the strong concentration of iron during cultivation process influence not only on ferritin synthesis, but also on synthesis another antioxidants, such as tocopherols and tocotrienols, $\beta$-carotene, phenolic compounds.

\section{Materials and methods}

\section{Chemicals}

Methanol (HPLC-grade) and Folin-Ciocalteu reagent, 2,2'diphenyl-1-picrylhydrazyl radical (DPPH), bovine serum albumin (BSA), caffeic acid, and quercetin were purchased from Sigma (St. Louis, MO). The tocopherols, tocotrienols, and $\beta$-carotene were purchased from Merck (Darmstadt, Germany). 1,4-Dioxane and $n$-hexane (both HPLC-grade) were obtained from Merck (Darmstadt, Germany). All other solvents and chemicals used in this study were of analytical grade. Deionized water was used in the resin-based column chromatography while ultrapure water purified via the Milli-Q system (Millipore, Bedford, USA) was used during analysis and germination soybean seeds. Stock and working standard of tocopherols, tocotrienols, and $\beta$-carotene were prepared by dissolving these analytes in $n$-hexane solution. The standard solutions stored at $4{ }^{\circ} \mathrm{C}$ were stable for at least 1 month.

\section{Materials}

Soybean seeds (Glycine max, cultivars Naviko) were obtained from the Department of Genetics and Plant Breeding, Poznan University of Life Sciences, Poland, harvested in the summer of 2009.

\section{Soybean sprouts cultivation}

Seeds were soaked in $70 \%$ ethanol solution for $15 \mathrm{~min}$ at room temperature for disinfection. After washing out of ethanol from the seeds with tap and distilled water, dry soybean seeds were soaked for successive $12 \mathrm{~h}$ in $\mathrm{FeSO}_{4}$ solutions (0-25 $\left.\mathrm{mM} \mathrm{FeSO}_{4}\right)$. Afterward, samples were cultured in the special germination dishes for 7 days at room temperature and $12 \mathrm{~h}$ of daylight illumination. They were watered every day with fresh $\mathrm{FeSO}_{4}$ solution with respective concentrations. During this time, the radicle of the seed came out, and the seed's coat was torn. Finally, obtained sprouted seeds (radicle with cotyledons) were dried in a stream of warm $\left(40{ }^{\circ} \mathrm{C}\right)$ circulating air to $8-10 \%$ of moisture content. Samples of dried sprouted seeds were milled with an IKA M20 universal laboratory mill (IKA-Werke GmbH\&Co, Staufen, Germany) and stored in the powder form in tightly sealed containers at room temperature. The preparation obtained from three replications of culture was mixed together.

\section{Determination of ferritin iron content}

$1 \mathrm{~g}$ of milled powder was extracted with $20 \mathrm{~mL}$ of $6 \mathrm{M}$ $\mathrm{HCl}$ for $30 \mathrm{~min}$ at $80{ }^{\circ} \mathrm{C}$. Extracted inorganic iron, not chelated and not introduced into organic compounds, was determined after thiocyanate reaction spectrophotometrically $(\lambda=480 \mathrm{~nm})$ [23] and is called in the text: free iron. Total iron content was determined after samples mineralization by atomic absorption spectrometry $(\lambda=248.3$, slit of $0.15 \mathrm{~nm}$ ) [24]. The difference between total iron and inorganic iron content is considered to be the organic bounded iron (the ferritin iron) content.

Determination of lipids content

Gravimetric determination of total lipids content was determined by multiple continuous sample extraction with petroleum ether (a mixture of pentanes and hexanes with a 
boiling point of $35-40{ }^{\circ} \mathrm{C}$ ) (by $6 \mathrm{~h}$ ). Extraction was performed using an automatic Soxhlet Büchi Extraction System B-811 (Büchi Labortechnik AG, Flawil, Switzerland). Total lipid content in a sample was measured as recommended in the [25].

Tocopherols, tocotrienols, and $\beta$-carotene analysis

In order to determine tocopherols, tocotrienols and $\beta$-carotene content, samples of dried soybean sprouted seeds $(2 \mathrm{~g})$ were saponified using $60 \% \mathrm{KOH}(2 \mathrm{~mL})$, ethanol $(20 \mathrm{~mL})$, and pyrogallol $(0.5 \mathrm{~g})$. After $30 \mathrm{~min}$ of heating at the solvent boiling point $\left(78^{\circ} \mathrm{C}\right), 50 \mathrm{~mL}$ of $1 \% \mathrm{NaCl}$ solution were added and the samples were than cooled. The unsaponifiable substances were extracted using $50 \mathrm{~mL} n$-hexane/ethyl acetate $(90: 10 \mathrm{v} / \mathrm{v})[26,27]$. Tocopherols, tocotrienols, and $\beta$ carotene were qualitatively and quantitatively identified using liquid chromatography HPLC (Waters 600 Asc. Milford, MA, USA). The LiChrosorb Si60 column $(250 \times 4.6 \mathrm{~mm} ; 5 \mu \mathrm{m})$ was used. The mobile phase consisted of $n$-hexane and 1,4dioxane $(97: 3 \mathrm{v} / \mathrm{v})$. Flow rate was $1.5 \mathrm{~mL} / \mathrm{min}$. The fluorometric detector (Waters 474 Asc. Milford, MA, USA) worked at excitation $\lambda=290 \mathrm{~nm}$ and emision $\lambda=330 \mathrm{~nm}$ for tocochromanols. $\beta$-carotene content was analyzed by UV-Vis spectrophotometry $(450 \mathrm{~nm})$ (PDA detector, Waters 2998 Asc. Milford, MA, USA). Concentrations of individual tocochromanol homologues and $\beta$-carotene were calculated from a previously prepared calibration curve. The limits of detection (LOD) and quantitation (LOQ) calculated at a signal-to-noise ratio of 3 and 10 (noise calculated peak to peak on a blank chromatogram at the tocopherols retention time) were 8 and $20 \mathrm{ng} / \mathrm{mL}$, respectively.

Methanol extracts of phenolic compounds

All samples were defatted using an automatic Soxhlet Büchi Extraction System B-811 (Büchi Labortechnik AG, Flawil, Switzerland). The extraction with $n$-hexane was carried out for $2 \mathrm{~h}$. To obtain soybean phenols, each sample was extracted three times with $80 \%$ methanol. In brief, $5 \mathrm{~g}$ of sample were extracted with $50 \mathrm{~mL}$ methanol three separate stages overly for $30 \mathrm{~min}$, at $50{ }^{\circ} \mathrm{C}$ temperature. After centrifugation $(10 \mathrm{~min}$ at $5,000 \mathrm{~g}$ ) (model 6K15, Sigma, Osterode am Harz, Germany), the precipitate was re-extracted twice more following the same steps. The three supernatants were combined and evaporated under reduced pressure using an R-215 rotorvapor (Büchi Labortechnik AG, Flawil, Switzerland) to a volume $25 \mathrm{~mL}$.

Total phenolics content

The total phenolics content in methanolic extract was determined by the Folin-Ciocalteu method [28]. An aliquot
$(0.2 \mathrm{~mL})$ of the methanolic extract was placed in a volumetric flask $(10 \mathrm{~mL})$. Diluted Folin-Ciocalteu reagent $(0.5 \mathrm{~mL})$ was added. Saturated solution of sodium carbonate $(1 \mathrm{~mL})$ was added after $3 \mathrm{~min}$. The flask was filled with water up to $10 \mathrm{~mL}$. Absorbance at $\lambda_{\max } 725 \mathrm{~nm}$ against a reagent blank was measured after $1 \mathrm{~h}$ using a UV-Vis spectrophotometer SP 8001 (Metertech Inc., Taipei, Taiwan). Caffeic acid $(0-90 \mu \mathrm{g} / \mathrm{mL})$ was used to produce standard calibration curve $\mathrm{y}=117.48 \mathrm{x}$ $\left(R^{2}=0.9986\right)$. The total phenolic content was expressed in $\mathrm{mg}$ of caffeic acid equivalents (CAE)/g dry plant material [29].

Total flavonoid content

Total flavonoid content was measured by the aluminum chloride colorimetric assay using a method based on the formation of complex flavonoid-aluminium. An aliquot $(1 \mathrm{~mL})$ of extracts was added to $10 \mathrm{~mL}$ volumetric flask containing $4 \mathrm{~mL} \mathrm{H}_{2} \mathrm{O}$. To the flask, $0.3 \mathrm{~mL} 5 \% \mathrm{NaNO}_{2}$ was added. After $5 \mathrm{~min}, 0.3 \mathrm{~mL} 10 \% \mathrm{AlCl}_{3}$ was added. At the 6th $\mathrm{min}, 2 \mathrm{~mL} 1 \mathrm{M} \mathrm{NaOH}$ solution was added and the total volume was made up to $10 \mathrm{~mL}$ with $\mathrm{H}_{2} \mathrm{O}$. The solution was mixed well, and the absorbance was measured against prepared reagent blank at $510 \mathrm{~nm}$, using a UV-Vis spectrophotometer SP 8001 (Metertech Inc., Taipei, Taiwan). Quercetin $(0-30 \mu \mathrm{g} / \mathrm{mL})$ was used to produce standard calibration curve $\mathrm{y}=0.0396 \mathrm{x}\left(R^{2}=0.9897\right)$. The total flavonoid content was expressed in $\mu \mathrm{g}$ of quercetin equivalents $(\mathrm{QE}) / \mathrm{g}$ dry plant material.

\section{DPPH radical scavenging method for measuring} antioxidant activity

The method consisted of spectrophotometric measurement of the intensity of the color change in solution depending on the amount of $\mathrm{DPPH}^{\bullet}$ (2,2-diphenyl-1-picrylhydrazyl radical). The reaction was initiated by mixing $1 \mathrm{~mL}$ of the methanolic extract with $3 \mathrm{~mL}$ methanol and then adding $1 \mathrm{~mL}$ of $\mathrm{DPPH}^{\bullet}(0.012 \mathrm{~g} / 100 \mathrm{~mL})$. Absorbance at $\lambda_{\max }$ of $517 \mathrm{~nm}$ (UV-Vis spectrophotometer SP 8001 Metertech Inc., Taipei, Taiwan) was checked at $0,0.5$, and at every $0.5 \mathrm{~min}$ until the reaction reached a stable state. This plateau was reached within $60 \mathrm{~min}$. The activity of the extract in scavenging $\mathrm{DPPH}^{\bullet}$ was calculated as follows:

$$
\begin{aligned}
& \% \mathrm{DPPH}^{\bullet} \text { scavening } \\
& =\left[\frac{\text { Absorbance of control }- \text { absorbance of sample }}{\text { absorbance of control }} \times 100 \%\right]
\end{aligned}
$$

Total antioxidant capacity is expressed also as Trolox equivalent on the basis of standard curve $\mathrm{y}=0.3964 \mathrm{x}$ $\left(R^{2}=0.9968\right)$. In order to compare, total antioxidant 
activity of obtained preparations additionally antiradical power (ARP) parameter was assayed [30]:

$\mathrm{ARP}=\frac{1}{\left(\mathrm{EC}_{50}\right)}$

$\mathrm{EC}_{50}$-antioxidant activities were expressed as the $\mathrm{EC}_{50}$, that is, the concentration of antioxidant required to cause a $50 \%$ reduction in the original concentration of DPPH. For ease of interpretation, antiradical powers were also calculated and defined as the inverse of the $\mathrm{EC}_{50}$ value.

\section{Statistical analysis}

Results are presented as means \pm standard deviation from three replicates of each experiment. $P$ value $<0.05$ was used to denote significant differences between mean values determined by the analysis of variance (ANOVA) using Statistica 7.0 (StatSoft, Inc., Tulsa, OK) software. Correlations were estimated using Pearson's correlation coefficient $(r)$.

\section{Results and discussion}

The soybean sprouted seeds fortified in iron may be proposed for preparation of iron supplements. In the presented experiment, the seeds were watered with $\mathrm{FeSO}_{4}$ solutions (5-25 mM) or only with water (reference sample) in order to obtain sprouted soybean seeds fortified in iron. The germinating seeds watered with $\mathrm{FeSO}_{4}$ solutions developed in abiotic stress conditions. They were both shorter and thicker and had a different color in comparison to the reference sample. In used higher concentrations of $\mathrm{FeSO}_{4}$ (20-25 $\mathrm{mM} \mathrm{FeSO}_{4}$ ) in the culture medium, the germination process was strongly inhibited, however, not stopped. After 7 days of culturing, dried and ground samples of radicles with cotyledons were used for analysis.

Range of plant resistance to metal toxicity and deficiency is variable. It depends both the element as well as plant species. This range for sprouting soybean seeds was established experimentally and included concentration 0-25 $\mathrm{mM}$ of $\mathrm{Fe}^{2+}$ ions. Exceeding the tolerance level of a particular plant species to the examined elements (called a critical point) causes a decrease in biomass production. Extremally high doses of toxic elements may lead to death of the plant [31].

The presence of toxic metals $(\mathrm{Fe}, \mathrm{Cu}, \mathrm{Zn}, \mathrm{Cd})$ in cells leads to oxidative stress. In these conditions, more reactive oxygen species (ROS) and free radicals (FR) are generated than it is metabolized. Present in cells ROS and free radicals cause lipid peroxidation (which leads to damage of cell membranes and the membranes inside the cell), destroy the structure of nucleic acids (which may be a reason for mutagenesis), oxidize proteins (leading to changes in structure and their inactivation), and inactivate the photosynthetic electron transport chain [32, 33].

Under the conditions of abiotic stress, particularly induced by high levels of iron ions in the environment, overexpression of ferritin is observed. This protein is responsible for the uptake of toxic iron, preventing the formation of ROS. Only small amounts of iron can be made ready for use by ${ }^{-} \mathrm{O}_{2}, \mathrm{H}_{2} \mathrm{O}_{2}$ from phytoferritin shell and participate in radical chemistry [34]. Briat et al. [35] show that the lack of ferritin gene in the seeds leads to greater sensitivity to methylviologen (pro-oxidant compounds) during germination. Thus, it is evident that antioxidative function of ferritin in plants is very important for iron sequestration to avoid oxidative stress.

During germination in standard conditions, native ferritin is degraded and iron from mineral core is mobilized for the growth of the seedlings. Formation of free radical scavengers, which are induced by the free iron presence or ferrous iron chelators inhibit in vitro degradation of ferritin. The storage form of ferritin is expressed as a result of elevated free iron in cellular fluid. These data lead to the hypothesis that a similar mechanism occurs during seedling germination [36, 37].

In standard germination conditions, production of ROS in cells is low [38] because the level of released iron from ferritin is also low and the ions are involved with synthesis of proteins, which takes part in photosynthesis, respiration or DNA synthesis processes [37]. Plant growth in high concentrated solution of $\mathrm{FeSO}_{4}$ leads to overexpression of ferritin. Increased concentration of ferrous iron in culture medium activates ferroxidase, which is responsible for uptake of iron by ferritin [39]. The changes in ferritin iron concentration were inferred from the observed changes in difference between the total iron content and free inorganic iron content built-in obtained sprouted seeds (Table 1). The level of ferritin iron was the highest in examined material obtained from cultures carried out in $20 \mathrm{mM}$ of $\mathrm{FeSO}_{4}$. It was 67 times higher than for sprouts germinated in distilled water. It may be concluded that up to this concentration, the defense of plant against oxidative stress is connected with introducing iron into ferritin. Observed decrease of total iron content and simultaneous increase in inorganic $\mathrm{Fe}^{2+}$ content in sprouts cultured in $25 \mathrm{mM}$ of $\mathrm{FeSO}_{4}$ confirm observed plant necrobiosis, which was the result of excessively high concentration of heavy metal in culturing medium.

During plants germination, reserves of lipids cumulated in seeds are utilized [34]. In the first stage of germination, storage proteins are degraded to amino acids. Next, synthesized enzymes (e.g., lipases) are used for the mobilization of the storage lipids. The glycerol formed by the hydrolysis of triacylglycerol can be fed into the 
Table 1 Total, inorganic $\left(\mathrm{Fe}^{2+}\right.$ and $\left.\mathrm{Fe}^{3+}\right)$, and ferritin iron content $(\mathrm{mg} / 100 \mathrm{~g}$ dry matter) in seeds and sprouted soybean seeds germinated in different $\mathrm{FeSO}_{4}$ concentrations $(0-25 \mathrm{mM})$

\begin{tabular}{lccccc}
\hline Sample & $\begin{array}{l}\text { The concentration of FeSO } \\
\text { culture medium }(\mathrm{mM})\end{array}$ & $\begin{array}{l}\text { Ferritin iron content } \\
(\mathrm{mg} / 100 \mathrm{~g} \mathrm{~d} . \mathrm{m} .)^{*}\end{array}$ & $\begin{array}{l}\mathrm{Fe}^{2+} \text { content } \\
(\mathrm{mg} / 100 \mathrm{~g} \mathrm{~d} . \mathrm{m} .)^{*}\end{array}$ & $\begin{array}{l}\mathrm{Fe}^{3+} \text { content } \\
(\mathrm{mg} / 100 \mathrm{~g} \mathrm{~d} . \mathrm{m} .)^{*}\end{array}$ & $\begin{array}{l}\text { Total iron content } \\
(\mathrm{mg} / 100 \mathrm{~g} \mathrm{~d} . \mathrm{m} .)^{*}\end{array}$ \\
\hline Soybean seeds & - & $2.72 \pm 0.71^{\mathrm{a}}$ & $3.21 \pm 0.25^{\mathrm{a}}$ & $5.36 \pm 0.22^{\mathrm{a}}$ & $11.29 \pm 0.75^{\mathrm{a}}$ \\
Sprouted soybean seeds & 0 & $1.79 \pm 1.00^{\mathrm{a}}$ & $4.28 \pm 0.65^{\mathrm{a}}$ & $4.28 \pm 0.34^{\mathrm{a}}$ & $11.07 \pm 0.99^{\mathrm{a}}$ \\
& 5 & $122.58 \pm 9.99^{\mathrm{b}}$ & $5.41 \pm 0.88^{\mathrm{a}}$ & $5.41 \pm 0.40^{\mathrm{a}}$ & $133.40 \pm 8.25^{\mathrm{b}}$ \\
& 10 & $163.86 \pm 10.34^{\mathrm{c}}$ & $7.55 \pm 0.74^{\mathrm{a}}$ & $7.55 \pm 0.69^{\mathrm{a}, \mathrm{b}}$ & $193.11 \pm 12.54^{\mathrm{c}}$ \\
& 15 & $139.08 \pm 11.67^{\mathrm{b}}$ & $33.03 \pm 1.56^{\mathrm{b}}$ & $11.91 \pm 0.78^{\mathrm{b}}$ & $199.27 \pm 14.32^{\mathrm{c}}$ \\
& 20 & $183.72 \pm 11.45^{\mathrm{d}}$ & $35.00 \pm 2.14^{\mathrm{b}}$ & $70.55 \pm 4.52^{\mathrm{d}}$ & $311.56 \pm 13.25^{\mathrm{d}}$ \\
& 25 & $174.95 \pm 27.46^{\mathrm{d}}$ & $62.92 \pm 5.24^{\mathrm{c}}$ & $18.82 \pm 1.04^{\mathrm{c}}$ & $276.08 \pm 32.25^{\mathrm{d}}$ \\
\hline
\end{tabular}

* Letters in a column show statistically significant differences at $P<0.05$

gluconeogenesis pathway. Free fatty acids, which are simultaneously formed are first activated by CoA-thioesters. Next, in $\beta$-oxidation process is degraded to acetylCoA. As a result of $\beta$-oxidation and glyoxylate cycle, succinate particle is formed from two acetyl-CoA particles. The succinate is transferred to the mitochondria and converted there to oxaloacetate. Next, oxaloacetate in cytosol is converted into phosphoenolpyruvate, which is the precursor of hexoses synthesis (gluconeogenesis pathway) [40]. During this conversion, toxic $\mathrm{H}_{2} \mathrm{O}_{2}$ and glyoxylate are formed. These molecules are immediately degraded, because even a small amount of these substances causes complete inhibition of photosynthesis in chloroplasts. However, during examination of Arabidopsis development, it was observed that storage oil mobilization is not essential for seed germination but is essential for seedling establishment [41].

In the presented experiment, mobilization of lipids during plant development was observed. Changes in fats content during examined germination processes are presented in Table 2. At lower concentrations of $\mathrm{FeSO}_{4}$ in culture medium $(0-10 \mathrm{mM})$, observed results are consistent with the general tendency. Fats content decreases slightly. However, increasing the concentration of $\mathrm{Fe}^{2+}$ causes a weak increase in lipids content in obtained sprouts in comparison to sprouts cultured in distilled water. No significant difference to raw seeds was observed.

Changes in the expression of ferritin and lipids content in abiotic stress conditions may influence the synthesis of fat-soluble antioxidant, such as tocopherols and tocotrienols and $\beta$-carotene. Soybean seeds are well known as a tocochromanol source, which are a group of major biological antioxidant. Tocopherols and tocotrienols are synthesized in higher plants plastids. During germination, the content of tocochromanol decreases, because they protect stored lipids from oxidation [42, 43]. For some species, decrease only of $\gamma$-tocopherol is observed and synthesis of others tocochromanols [44]. Some authors suggest that content of $\alpha$-tocopherols changes depending on conditions of germination, as availability of light [21, 44-47]. The main tocopherol (Table 2) of seeds, it means $\gamma$-tocopherol, decreases in prepared sprouted soybean seeds (down to $78-88 \%$ ) and this is an ordinary trend observed during germination [48]. Even though the growth of sprouts is strongly limited in $25 \mathrm{mM} \mathrm{FeSO}$, the reduction of $\gamma$-tocopherol is still high. $\alpha$-Tocopherol content in sprouted seeds enriched in $\mathrm{Fe}^{2+}$ achieved $82-114 \%$ of $\alpha$-tocopherol in seeds. The reduction of $\delta$-tocopherol reaches only $8-14 \%$ and content of $\beta$-tocopherol changes in range $87-123 \%$ in comparison to seeds. $\beta$-Tocotrienol content is reduced to $77-93 \%$ but $\gamma$-tocotrienol reaches $95-118 \%$ of their content in seeds (Table 2).

However, even though the tocochromanol content in sprouts cultured in stress conditions is always lower than their level in seeds, it is also always higher than in sprouted seeds raising in distilled water. The highest content of total tocochromanols was achieved in sprouted seeds germinated in $10 \mathrm{mM} \mathrm{FeSO}_{4}$ solution (93\% of tocochromanol of seeds) (Table 2). It should be noted that observed changes may result both from culturing conditions and the way of obtained sprouts preparation, first of all drying in circulating air and storage at room temperature.

Another fat-soluble antioxidant is $\beta$-carotene. Carotenoids protect unsaturated lipids, triacylglycerols, proteins, and membranes from photooxidation [49]. During germination, depending on accessibility and type of illumination, $\beta$-carotene content is increased. In presented experiment, germination of seeds in ordinary conditions (water) caused more than 11-fold increase in $\beta$-carotene content (Table 2). Abiotic stress strongly affected synthesis of $\beta$-carotene. Raising in $10 \mathrm{mM}$ of $\mathrm{FeSO}_{4}$ sprouts induced almost 28 times higher $\beta$-carotene accumulation than in raw seeds and 2.5 times higher than in sprouted seeds germinated in water. Further increasing of $\mathrm{Fe}^{2+}$ concentration in culture medium rapidly decreased the content of examined provitamin.

The elevated synthesis of $\beta$-carotene in the presence of iron ions was observed previously [50]. Kobayashi et al. 


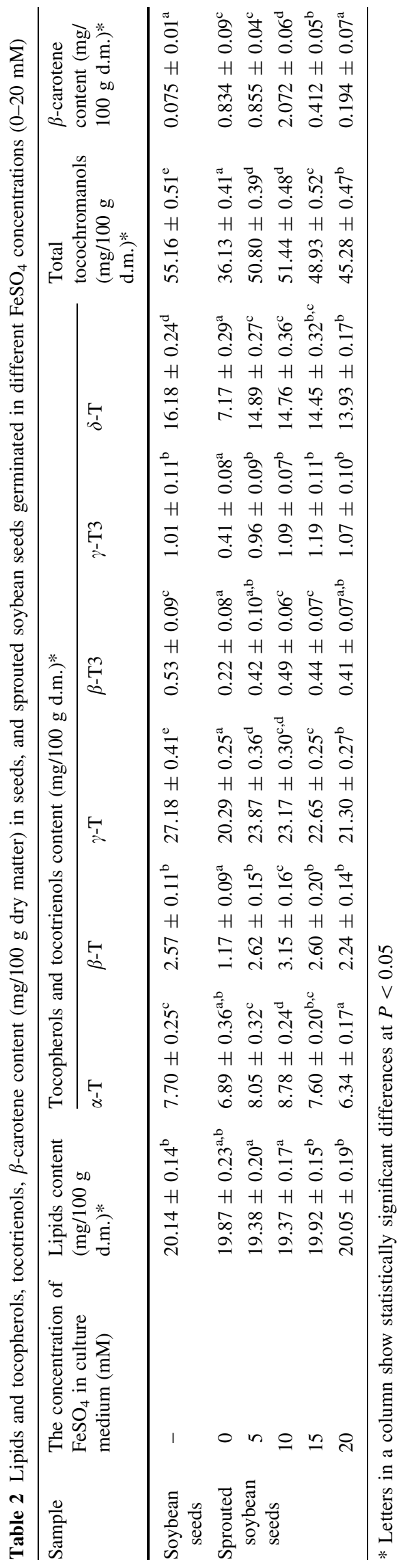

[50] confirmed that generation of hydroxyl radical is important in the process of carotenogenesis activation.

The impact of used stress conditions was not evident for the next group of examined antioxidant. An increase $(\sim 29 \%)$ in total phenolic content was noted during germination in distilled water in comparison to the in raw seeds (Table 3). It was observed before that germination causes an increase in phenolic compound content up to 7-9 days of culturing [47, 51]. The total phenolic compounds content assayed for sprouts cultured in stress conditions was always smaller. The highest total phenolic compounds content was noted for sprouts raising in 5-10 $\mathrm{mM} \mathrm{FeSO}_{4}$ solutions, and it was $119-123 \%$ of total phenolic compound content assayed in raw seeds. However, the changes were statistically not significant.

Flavonoids are $\sim 11 \%$ of phenolic compounds, and this tendency is observed for every obtained preparation (Table 3).

Table 3 presents also the changes in antioxidant capacity expressed as Trolox ( $\mu \mathrm{M} / \mathrm{L})$ and ARP. Generally, the germination of seeds is the process, which improves their antioxidant activity [21] as it was seen for soybean seeds cultured in $0-10 \mathrm{mM} \mathrm{FeSO}{ }_{4}$ concentrations. However, in higher stress conditions $\left(15-25 \mathrm{mM}\right.$ of $\left.\mathrm{FeSO}_{4}\right)$, it is continuously decreased and even lower than for raw seeds. The changes in antioxidant activity may also confirm that in concentrations of $\mathrm{FeSO}_{4}$ higher than $15 \mathrm{mM}$, oxidative stress is so high, that it starts to inhibit plant development. However, the growth of the sprouts was still observed. An increase in antioxidant activity may result from changes in total phenolic compounds content. The correlation between antioxidant activity and the content of total phenolic compounds reaches the value $r=0.8498$.

\section{Conclusion}

In the present investigation, sprouts enriched in ferritin were cultured in order to obtain an edible part of plants fortified in ferritin. The highest accumulation of ferritin was observed during cultivation in $20 \mathrm{mM} \mathrm{FeSO}_{4}$ solutions.

The ferritin is a major antioxidant that protects cells against toxic iron in these conditions. However, stress conditions cause also an increase of $\beta$-carotene synthesis. Antioxidant activity was correlated to the total phenolic content and increased both in the sprouts cultured in water and in lower concentrations of $\mathrm{FeSO}_{4}$. Development of plant in high concentration of $\mathrm{FeSO}_{4}$ influences hydrolysis of lipids. Tocochromanols participation in protecting cells against oxidation is lower than observed in raw seeds. Germination of seeds in stress conditions strongly influences development of sprouts. Reactive oxygen species is formed not only as a consequence of hydrolytic processes, how it may be observed for germination in water. 
Table 3 Total phenolic compounds, flavonoid content ( $\mathrm{mg} / 100 \mathrm{~g}$ dry matter), and antioxidant capacity in soybean seeds and sprouted seeds germinated in different $\mathrm{FeSO}_{4}$ solutions $(0-25 \mathrm{mM})$

\begin{tabular}{lllllll}
\hline Sample & $\begin{array}{l}\text { The concentration of FeSO } \\
\text { in culture medium }(\mathrm{mM})\end{array}$ & $\begin{array}{l}\text { Total phenolic } \\
\text { compounds } \\
(\mathrm{mg} / \mathrm{g} \mathrm{d} . \mathrm{m} .)^{*}\end{array}$ & $\begin{array}{l}\text { Flavonoids } \\
(\mathrm{mg} / \mathrm{g} \mathrm{d} . \mathrm{m} .)^{*}\end{array}$ & $\begin{array}{l}\text { Trolox } \\
(\mu \mathrm{M} / \mathrm{L})^{*}\end{array}$ & $\begin{array}{l}\text { EC50 } \\
(\mu \mathrm{g} / \mathrm{mL})^{*}\end{array}$ & $\begin{array}{l}\text { ARP } \\
\left(\times 10^{-3}\right)^{*}\end{array}$ \\
\hline Soybean seeds & - & $1.63 \pm 0.21^{\mathrm{a}}$ & $0.180 \pm 0.04^{\mathrm{a}}$ & $623.12 \pm 11.16^{\mathrm{c}}$ & 0.42 & $2.38 \pm 0.20^{\mathrm{a}, \mathrm{b}}$ \\
Sprouted soybean seeds & 0 & $2.10 \pm 0.15^{\mathrm{a}}$ & $0.229 \pm 0.06^{\mathrm{a}}$ & $716.56 \pm 22.21^{\mathrm{d}}$ & 0.36 & $2.79 \pm 0.10^{\mathrm{b}, \mathrm{c}}$ \\
& 5 & $1.94 \pm 0.11^{\mathrm{a}}$ & $0.199 \pm 0.03^{\mathrm{a}}$ & $711.32 \pm 15.01^{\mathrm{d}}$ & 0.35 & $2.84 \pm 0.15^{\mathrm{c}}$ \\
& 10 & $2.01 \pm 0.09^{\mathrm{a}}$ & $0.214 \pm 0.05^{\mathrm{a}}$ & $732.60 \pm 11.85^{\mathrm{d}}$ & 0.33 & $2.98 \pm 0.14^{\mathrm{c}}$ \\
& 15 & $1.78 \pm 0.16^{\mathrm{a}}$ & $0.190 \pm 0.01^{\mathrm{a}}$ & $581.72 \pm 16.77^{\mathrm{b}}$ & 0.43 & $2.32 \pm 0.21^{\mathrm{a}}$ \\
& 20 & $1.71 \pm 0.12^{\mathrm{a}}$ & $0.184 \pm 0.02^{\mathrm{a}}$ & $537.68 \pm 12.45^{\mathrm{a}}$ & 0.46 & $2.16 \pm 0.16^{\mathrm{a}}$ \\
& 25 & $1.68 \pm 0.18^{\mathrm{a}}$ & $0.180 \pm 0.03^{\mathrm{a}}$ & $530.32 \pm 19.56^{\mathrm{a}}$ & 0.46 & $2.18 \pm 0.11^{\mathrm{a}}$ \\
\hline
\end{tabular}

* Letters in a column show statistically significant differences at $P<0.05$

Acknowledgments The authors acknowledge financial support by the Ministry of Science and Higher Education of the Republic of Poland (Project N312 029 31/2098).

Open Access This article is distributed under the terms of the Creative Commons Attribution License which permits any use, distribution, and reproduction in any medium, provided the original author(s) and the source are credited.

\section{References}

1. Andrews NC (1995) Disorders of iron metabolism. N Engl J Med 341:1986-1995

2. Kushner JP, Porter JP, Olivieri NF (2001) Secondary iron overload. Hematology Am Soc Hematol Educ Program 1:47-61

3. Rouault TA (2003) Hepatic iron overload in alcoholic liver disease: why does it occur and what is its role in pathogenesis? Alcohol 30:103-106

4. Weiss G (2002) Pathogenesis and treatment of anaemia of chronic disease. Blood Rev 16:87-96

5. WHO (2000) Turning the tide of malnutrition: responding to the challenge of the 21 st century. Geneva (WHO/NHD.007)

6. Hunt JR (2003) Supplements bioavailability of iron, zinc, and other trace minerals from vegetarian diets. Am J Clin Nutr 78(3):633S-639S

7. Fleming RE, Bacon BR (2005) Orchestration of iron homeostasis. NEJM 352(17):1741-1744

8. Hurrell RF (1997) Preventing iron deficiency through food fortification. Nutr Rev 55:210-222

9. Uauy R, Hertrampf E, Reddy M (2002) Iron fortification of foods: overcoming technical and practical barriers. J Nutr 132:849S$852 \mathrm{~S}$

10. Stoltzfus RJ, Dreyfuss ML (1998) Guidelines for the use of iron supplements to prevent and treat iron deficiency anemia. ILSI Press, Washington

11. White PJ, Broadley MR (2009) Biofortification of crops with seven mineral elements often lacking in human diets-iron, zinc, copper, calcium, magnesium, selenium and iodine. New Phytol $182: 49-84$

12. Curie C, Briat JF (2003) Iron transport and signaling in plants. Ann Rev Plant Biol 2003:183-206

13. Briat J-F, Lobreaux S (1998) Iron storage and ferritin in plants. Met Ions Biol Syst 35:563-583
14. Harrison PM, Arosio P (1996) The ferritins: molecular properties, iron storage function and cellular regulation. Biochem Biophys Acta 1275:161-203

15. Theil EC, Briat JF (2004) Plant ferritin and non-heme iron nutrition in humans. HarvestPlus technical monograph 1. Washington, DC

16. Savelkoul FHMG, Boer H, Tamminga S, Schepers AJ, Elbourg L (1992) In vitro enzymatic hydrolysis of protein and protein pattern change of soya and faba beans during germination. Plant Foods Hum Nut 42:275-284

17. Bau H-M, Villaume C, Nicolas J-P, Méjean L (1997) Effect of germination on chemical composition of biochemical constituents and antinutritional factors of soya bean (Glycine max) seeds. J Sci Food Agric 73:1-9

18. Suda M, Watanabe T, Kobayashi M, Matsuda K (1986) Changes in starch content and related enzymes activities during the growth of germinating soybeans. Agric Biol Chem 50:3195-3196

19. Chandrasiri V, Bau HM, Villaume C, Giannangeli F, Lorient F, Méjean L (1987) Effect de la germinationde la graine de soja sur la composition et la valeur nutritionnelle de sa farine. Sci Aliments 7:139-150

20. Khalil AH, Mansour EH (1995) The effect of cooking, autoclaving and germination on the nutritional value of faba beans. Food Chem 54:177-182

21. Fernandez-Orozco R, Piskula MK, Zieliński H, Kozłowska H, Frias J, Vidal-Valverde C (2006) Germination as a process to improve the antioxidant capacity of Lupinus angustofilus L. var. Zapaton Eur Food Res Technol 223:495-502

22. Torres A, Frías J, Granito M, Guerra M, Vidal-Valverde C (2007) Free $\alpha$-galactosides lupine flour as pasta ingredient: chemical, biological and sensory evaluation. J Sci Food Agric 87:74-81

23. Sandell EB (1959) Colorimetric determination of traces of metals. Interscience Publishers Inc, New York

24. Tsalev DL, Zaprianov ZK (1984) Atomic absorption spectrometry in occupational and enviromental healths practice: determination of individual elements. CRC Press, Boca Raton

25. Current protocols in food analytical chemistry (2001) Extraction and measurement of total lipids. John Wiley \& Sons, Inc. D1.1.1D1.1.11

26. Ryynänen $M$, Lampi $A M$, Salo-Väänänen $P$, Ollilainen $V$, Piironen V (2004) A small-scale sample preparation method with HPLC analysis for determination of tocopherols and tocotrienols in cereals. J Food Comp Anal 17:749-765

27. Singleton VL, Rossi JA (1965) Colorimetry of total phenolics with phosphomolibdicphosphotungstic acid reagent. Am J Enol Viticul 16:144-158 
28. Siger A, Nogala-Kałucka M, Lampart-Szczapa E (2008) The content and antioxidant activity of phenolic compounds in coldpressed plant oils. J Food Lipid 15:137-149

29. Zhishen J, Mengcheng T, Jianming W (1999) Research on antioxidant activity of flavonoids from natural materials. Food Chem 64:555-559

30. Suja KP, Jayalekshmy A, Arumughan C (2005) Antioxidant activity of sesame cake extract. Food Chem 91:213-219

31. Woźny A (1997) Responses of plant cells to trace (heavy) elements of ecosystems. Idee Ekol 10:35-57

32. Benavides MP, Gallego SM, Tomaro ML (2005) Cadmium toxicity in plants. Braz J Physiol 17:21-34

33. Tripathi BN, Gaur JP (2004) Relationship between copper- and zinc-induced oxidative stress and proline accumulation in Scenedesmus sp. Planta 219:397-404

34. Gilbert DL, Colton CA (2002) Reactive oxygen species in biological systems: an interdisciplinary approach. Kluwer Academic Publishers, New York

35. Briet JF, Duc C, Ravet K, Gaymard F (2010) Ferritins and iron storage in plants. Bioch Bioph Acta 1800:806-814

36. Lobreaux S, Briat JF (1991) Ferritin accumulation and degradation in different organs of pea (Pisum sativum) during development. Biochem J 274:601-606

37. Briat JF, Lobreaux S, Grignon N, Vansuyt G (1999) Regulation of plant ferritin synthesis: how and why. Cell Mol Life Sci $56: 155-166$

38. Dubey RS (2010) In: Gupta SD (ed) Reactive oxygen species and antioxidants in higher plants. CRC Press, Boca Raton

39. Laulhère JP, Briat JF (1993) Iron release and uptake by plant ferritin as affected by $\mathrm{pH}$, reduction and chelation. Biochem $\mathrm{J}$ 290:693-699
40. Heldt HW (2005) Plant biochemistry. Elsevier Academic Press, San Diego

41. Graham IA (2008) Seed storage oil mobilization. Annu Rev Plant Biol 59:115-142

42. Eitenmiller RR, Lee J (2004) Vitamin E: food chemistry, composition and analysis. Marcel Dekker Inc., New York

43. Sattler SE, Giliand LU, Magallanes-Lundback M, Pollard M, DellaPenna D (2004) Vitamin E is essential for seed longevity and for preventing lipid peroxidation during germination. Plant Cell 16:1419-1432

44. Zieliński H, Kozłowska H (2003) The content of tocopherols in Cruciferae sprouts. Pol J Food Nutr Sci 4:25-31

45. Frias J, Miranda ML, Doblado R, Vidal-Valverde C (2005) Effect of germination and fermentation on the antioxidant vitamin content and antioxidant capacity of Lupinus albus L. ver. Multolupa. Food Chem 92:211-220

46. Friedrich W (1988) Vitamins. Walter de Gruyter Inc., Berlin

47. Zieliński H (2003) Contribution of low molecular weight antioxidants to the antioxidant screen of germinated soybean seeds. Plant Food Hum Nutr 58:1-20

48. Smirnoff N (2005) In: Smirnoff N (ed) Antioxidents and reactive oxygen species in plant. Blackwell Publishing Ltd., Oxford

49. DellaPenna D, Pogson BJ (2006) Vitamin synthesis in plants: tocopherols and carotenoids. Annu Rev Plant Biol 57:711-738

50. Kobayashi M, Kakizono T, Nagai S (1993) Enhanced carotenoid biosynthesis by oxidative stress in acetate-induced cyst cells of a green unicellular alga, Haematococcus pluvialis. App Environ Microbiol 59:867-873

51. White PJ, Xing Y (1997) In: Shahidi F (ed) Natural antioxidants: chemistry, health, effects and applications. AOCS Press 